\title{
Preliminary response of Sandhills prairie to fire and bison grazing
}

\author{
KENT E. PFEIFFER AND ALLEN A. STEUTER
}

\begin{abstract}
Authors are graduate student, Division of Biology, Kansas State University, Manhattan 66506; and Director of Science and Stewardship, The Nature Conservancy, Rt. 1, Box 348, Johnstown, Neb. 69214.
\end{abstract}

\section{Abstract}

This research determined the preliminary response of sandhills prairie to spring and summer prescribed burns, and their interaction with bison (Bison bison) grazing. Changes in species composition and standing crop were determined for paired (caged/uncaged) plots established in burned and unburned areas during the 1991 and 1992 growing seasons. End of season standing crop of both rhizomatous grasses and bunchgrasses was increased by spring burning on sands range sites. Summer burning did not affect rhizomatous grass standing crop, but dramatically reduced bunchgrass standing crop. On burned areas, bison grazing reduced bunchgrass standing crop by $56 \%$, while reducing rhizomatous grass standing crop by only $18 \%$. Forbs generally appeared unaffected by bison grazing and were affected variously by burning. The current bunchgrass composition of Nebraska Sandhills prairie appears dependent on fire exclusion. With fire, a replacement of bunchgrass with rhizomatous grasses may increase available forage, but also increase the risk of wind erosion, particularly on choppy sands range sites.

Keywords: fire effects, bison grazing, rhizomatous grass, bunchgrass, matrix forb, interstitial forb

After climate, fire, and large herbivores were the 2 most important forces responsible for creating and maintaining the grasslands of the Great Plains (Axelrod 1985, Anderson 1990). These 2 forces also had an important impact on Nebraska Sandhills prairie (Steuter et al. 1990). However, the use of fire has not been recommended as a management practice for these rangelands.

In the only published fire-grazing study conducted in the Nebraska Sandhills, Bragg (1978) reported that choppy sands range sites burned in a May wildfire, and later grazed by cattle, experienced a substantial reduction in vegetative cover and biomass compared to areas that were only grazed. Vegetative cover was reduced on a burned only area during the first post-fire growing season, but increased after 2 growing seasons. Forbs were generally reduced by fire and increased by grazing. The major rhizomatous grasses sand bluestem (Andropogon hallii Hack), and prairie sandreed (Calamovilfa longifolia (Hook.) Scribn.), are more tolerant of repeated clipping than the major bunchgrass little bluestem (Schizachyrium scoparium (Michx.) Nash) (Mullahey et al 1990, Mullahey et al 1991).

The purpose of this study was to determine the effects of fire and bison grazing on four groups of Sandhills prairie plants: rhizomatous grasses [primarily sand bluestem, prairie sandreed, and switchgrass

This research was supported by The Nature Conservancy and Kansas State University. Authors wish to thank D. E. Kuhre, F. R. Egelhoff, and D. M. Johnson for their help in field data collection and Drs. J. Stubbendieck and D. Engle for their help in improving the manuscript.

Manuscript accepted 25 Feb. 1994.
(Panicum virgatum $\mathrm{L}$.)], bunchgrasses (primarily little bluestem), matrix forbs (the dominant rhizomatous species), and interstitial forbs (mostly annuals and perennial taprooted species).

\section{Materials and Methods}

\section{Study Area}

Our study was conducted during the 1991 and 1992 growing seasons on The Nature Conservancy's Niobrara Valley Preserve in northcentral Nebraska. Study sites were located within a 3,000 ha pasture that has been grazed by bison since 1986 . Two hundred and fifty adult and yearling bison graze the enclosure year round (about 1.0 AUM/ha/yr stocking rate). Sandhills prairie occupies $90 \%$ of the study area. The topoededaphic units of these grasslands are identified as shallow-to-gravel, sands, and choppy sands range sites, with sands ranges sites occupying the majority of the area. The remaining $10 \%$ of the study area is a combination of riparian wetland-woodland-grassland communities within the valley of the Niobrara River. The grasslands are dominated by perennial, warm season grasses with sand bluestem, prairie sandreed, switchgrass, and little bluestem being the most common. Forbs, such as western ragweed (Ambrosia psilostachya DC.) and stiff sunflower (Helianthus rigidus (Cass.) Desf.), are common.

Vegetation sampling was restricted to sands range sites, the most abundant and productive of Sandhills upland range sites. Soils were Valentine fine sand (mixed, mesic Typic Ustipsamments). Annual precipitation was equal to the long-term average $(490 \mathrm{~mm})$ in 1991 , and $10 \%$ above average $(540 \mathrm{~mm})$ in 1992.

Prescribed burning was initiated within the bison pasture in 1991. Approximately 500 ha were burned in 2 prescribed burns in early May, and another 100 ha were burned in 2 prescribed fires in late July, 1991. All prescribed burns were headfires into downwind fuel breaks with relative humidity between $25 \%$ and $35 \%$, and winds 9 to 25 $\mathrm{km} / \mathrm{hr}$. Air temperature was $18^{\circ} \mathrm{C}$ and $26^{\circ} \mathrm{C}$, while fine fuel loads were approximately 1,500 and $1,200 \mathrm{~kg} / \mathrm{ha}$, during the early May and late July prescribed burns, respectively. No burning was conducted in 1992.

\section{Sampling Design}

Forty, paired plots were established on the study site in 1991. Bison were excluded from grazing 1 plot of each pair by $1 \mathrm{~m}^{2}$ cages constructed of heavy welded wire. Twenty pairs ( 20 grazed and 20 ungrazed) were randomly located, using a map of the bison area, in one of the spring burned areas and 20 pairs in an adjacent unburned area. Regrowth on the late July burns was not enough to warrant sampling in 1991. In 1992, the cages were relocated with the spring burned area and the summer burned area each containing 14 paired plots, and the unburned area 12 pairs. This arrangement resulted in 4 treatments in 1991: spring burned/grazed, spring burned/ungrazed, un- 
burned/grazed, and unburned/ungrazed. Two additional treatments were added in 1992: summer burned/grazed, and summer burned/ungrazed. Throughout the study, plots were established only on sands range sites.

Forb presence and stem density was sampled within $0.5 \mathrm{~m}^{2}$ quadrats from caged and uncaged plots in mid-June each year. In early August of each year, the current year growth of all species was clipped from the same $0.5 \mathrm{~m}^{2}$ quadrats, and separated into rhizomatous grass, bunchgrass, matrix forb [western ragweed, stiff sunflower, white sagewort (Artemisia ludoviciana Nutt.), and prairie goldenrod (Solidago missouriensis Nutt.)], and interstitial forb (annuals and taprooted perennials) components. Total herbage samples from each group were oven dried and weighed. Data were analyzed using a factorial design. Differences in treatment means were tested with Fisher's F-Protected L.S.D. at a significance level of $P<0.05$.

\section{Results and Discussion}

Current year's standing crop of grasses was increased by spring burning, and decreased by bison grazing on spring burns during the first post-fire growing season (Table 1). Current year grass standing crop in 1992 was highest, and similar, on the unburned, and spring burned/ungrazed treatments (Table 1). Grass standing crop was lowest on the summer burned/grazed treatment in the second post-fire growing season. There was no difference in forb standing crop in August of 1991 based on treatment (Table 1). Forb standing crop was significantly higher on the summer burned/ ungrazed plots compared to all other treatments in August of 1992 (Table 1).

Table 1. Standing crop $\left(\mathrm{g} / \mathrm{m}^{2}\right)$ of grass and forb groups by treatment, 1991 and 1992. Similar letters indicate no siginificant difference $(P>$ 0.05 ) between treatments.

\begin{tabular}{|c|c|c|c|c|c|c|}
\hline & \multicolumn{2}{|c|}{ Spring burned } & \multicolumn{2}{|c|}{ Summer bumed } & \multicolumn{2}{|c|}{ Unburned } \\
\hline & Grazed & Ungrazed & Grazed & Ungrazed & Grazed & igrazed \\
\hline 1991 & -..--... & 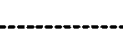 & $\cdots-($ & $\left.n^{2}\right)-$ & & \\
\hline Rhiz. Grass & $47.1 \mathrm{a}$ & $93.4 b$ & - & - & $61.3 \mathrm{c}$ & $72.6 \mathrm{c}$ \\
\hline Bunchgrass & $11.8 \mathrm{a}$ & $29.8 b$ & - & 一 & $26.1 b c$ & $13.0 \mathrm{c}$ \\
\hline Total Grass & $58.9 \mathrm{a}$ & $122.2 \mathrm{~b}$ & - & - & $87.4 c$ & $85.6 \mathrm{c}$ \\
\hline Total Forb & $10.2 \mathrm{a}$ & $18.5 \mathrm{a}$ & - & - & $12.4 \mathrm{a}$ & $14.4 \mathrm{a}$ \\
\hline 1992 & & & & & & \\
\hline Rhiz. Grass & $38.5 a$ & $41.2 \mathrm{a}$ & $12.2 \mathrm{~b}$ & 36.9ac & $26.7 \mathrm{c}$ & $28.8 \mathrm{c}$ \\
\hline Bunchgrass & $7.6 \mathrm{a}$ & $22.5 b$ & $1.5 \mathrm{c}$ & $4.6 \mathrm{a}$ & $38.6 \mathrm{~d}$ & 48.1d \\
\hline Total Grass & $46.1 \mathrm{a}$ & $63.7 \mathrm{~b}$ & $13.7 \mathrm{c}$ & $41.5 \mathrm{a}$ & $65.3 b$ & $76.9 \mathrm{~b}$ \\
\hline Total Forb & $18.2 \mathrm{a}$ & $20.8 a$ & $19.3 a$ & $55.0 \mathrm{~b}$ & $12.8 \mathrm{a}$ & $12.6 a$ \\
\hline
\end{tabular}

Rhizomatous grass standing crop was increased by spring burning for two growing seasons (Table 1). However, the interaction of spring fire and bison grazing significantly reduced rhizomatous grass standing crop in the first post-fire growing season (Table 1). During the second post-fire growing season the standing crop of rhizomatous grass on spring burned/bison grazed areas was equivalent to burned/ungrazed, and higher than unburned treatments (Table 1). Summer burning alone did not affect rhizomatous grass standing crop, but in combination with bison grazing it significantly reduced rhizomatous grass standing crop. We were unable to detect a change in rhizomatous grass standing crop on unburned areas as a result of bison grazing during the growing season.

Bunchgrass standing crop was also highest in the spring burned/ungrazed treatment, and lowest on the spring burned/grazed treatment in 1991 (Table 1). In the spring burned area, bunchgrasses were reduced relatively more by bison grazing than were rhizomatous grasses $(46 \%$ and $29 \%$, respectively) in the first post-fire growing season. However, this difference was not significant. During the second post-fire growing season, bunchgrass standing crop was reduced $66 \%$ and rhizomatous grass $7 \%$ on spring burned/grazed plots compared to spring burned/ungrazed treatments (Table 1). This difference was significant $(P<0.0001)$. Summer burning reduced bunchgrass standing crop by $90 \%$, and summer burning in combination with bison grazing reduced bunchgrass standing crop another $50 \%$ (Table 1). As with rhizomatous grasses, we could not detect a difference in bunchgrass standing crop on unburned areas grazed by bison during the growing season.

Bison had a larger and longer impact on bunchgrass regrowth than on rhizomatous grass regrowth after buming. Mack and Thompson (1982) suggested that the rhizomatous grasses of the Great Plains are better adapted to large herbivore grazing than are bunchgrasses. Little bluestem, a major Sandhills bunchgrass, has a low tolerance to grazing (Butler and Briske 1988, Mullahey et al. 1990). However, in the absence of fire, little bluestem accumulates a canopy of standing dead tillers which reduces grazing pressure. This canopy produces an intense fire around the growing points of a bunchgrass when a fire does occur (Wright 1971). The fire damage, combined with high regrowth removal rates by bison or cattle, may lead to a significant loss of bunchgrasses from Sandhills prairie. The current abundance of little bluestem, and other bunchgrasses, such as sand lovegrass (Eragrostis trichodes), may be due to the relatively recent fire exclusion policy.

As a group, forbs were not affected by the presence of bison grazing. Matrix forb stem density was not affected by spring burning, but was reduced $(P<0.0001)$ by summer burning (Table 2$)$. Western ragweed had the largest reduction.

Interstitial forbs were reduced by spring burning in the first postfire growing season (Table 2). By the second season, stem density in the spring burned area had returned to levels approximately equal to that in the unburned area (Table 2). Summer burning resulted in a large increase in stem density for interstitial forbs. Most of this increase was accounted for by annuals such as Missouri spurge (Euphorbia missouriensis) and Plains sunflower (Helianthus petoliaris).

Sandhills forbs responded primarily to fire treatments, rather than to bison grazing. This response is opposite to that reported by Bragg (1978) for choppy sands range sites impacted by fire and cattle grazing. However, our results are generally consistent with recent Great Plains studies involving fire and bison grazing (Biondini et al. 1989, Plumb and Dodd 1993, Steuter et al. 1994). The decline in interstitial forbs produced by early May fires is probably due directly to fire mortality. However, the large increase in interstitial forbs the year after the summer fires is more likely an indirect response to changes in plant root and soil nutrient patterns produced by the fire treatments (Biondini and Grygiel 1993). The large increase in interstitial forb density corresponds to equally large declines in bunchgrass standing crop and matrix forb density.

Table 2. Stem density (stems $/ \mathrm{m}^{2}$ ) of matrix and intersitial forbs by treatment, 1991 and 1992 . Similar letters indicate no significant differences $(P>0.05)$ between treatments.

\begin{tabular}{|c|c|c|c|c|c|c|}
\hline & \multicolumn{2}{|c|}{ Spring burned } & \multicolumn{2}{|c|}{ Summer bumed } & \multicolumn{2}{|c|}{ Unburned } \\
\hline & Grazed & Ungrazed & Grazed & Ungrazed & Grazed & Ungrazed \\
\hline \multirow{3}{*}{$\begin{array}{l}1991 \\
\text { Matrix Forbs } \\
\text { Inter. Forbs }\end{array}$} & & 列 & $(\mathrm{g} / 1$ & - & & 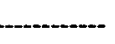 \\
\hline & $30.8 \mathrm{a}$ & $32.5 a$ & - & - & $26.8 \mathrm{a}$ & $34.3 \mathrm{a}$ \\
\hline & $1.8 \mathbf{a}$ & $3.3 a$ & - & - & $10.6 b$ & $9.0 b$ \\
\hline \multirow{3}{*}{$\begin{array}{l}1992 \\
\text { Matrix Forbs } \\
\text { Inter. Forbs }\end{array}$} & & & & & & \\
\hline & $33.5 a$ & $32.4 \mathrm{a}$ & $5.5 b$ & $3.7 \mathrm{~b}$ & $28.3 \mathrm{a}$ & $29.2 \mathrm{a}$ \\
\hline & $10.8 \mathrm{a}$ & $16.0 \mathrm{a}$ & $47.8 \mathrm{~b}$ & $50.5 b$ & $9.3 \mathrm{a}$ & $6.8 a$ \\
\hline
\end{tabular}




\section{Conclusions}

During the three growing seasons prior to burning, the bison on our study area selected for the perennial $C_{4}$ grasses which characterize the matrix vegetation on sands range sites (Steuter et al. 1994). The largest contiguous blocks of these productive, gently rolling range sites were highly preferred during the growing season. We expected burning to alter the grazing patterns of bison (Coppock and Detling 1986, Shaw and Carter 1990, Vinton et al. 1993) with burned areas to be grazed more heavily than unburned areas. This was true within the sands range site. At the large-scale, bison continued to prefer sands range sites and avoid choppy sands range sites during the growing seasons following fire.

In our study, rhizomatous grasses on sands range sites responded positively to fire, and the increased grazing pressure by bison lasted only one season. Thus, a combination of fire and grazing management may increase the standing crop of rhizomatous grasses at the expense of bunchgrasses. This would increase the amount of forage available since, in unburned prairie, bunchgrass forage is often underutilized due to the deterrent effect of standing dead tillers (Butler and Briske 1988). Yet, the bunchgrass' habit of maintaining 2 or 3 year's worth of upright dead tillers may reduce the risk of wind erosion in the Sandhills by deflecting the wind profile above the land surface (S.S. Waller per. comm.). This is an important consideration, especially on choppy sands ranges sites.

Our preliminary results of fire and large herbivore grazing in the Nebraska Sandhills emphasizes the dynamic history of the landscape. For example, the Sandhills landscape has undergone periods of large scale wind erosion and low vegetative cover (Bleed and Flowerday 1989) followed by periods of dune stabilization and relatively heavy vegetative cover. This is supported by Bragg (1985) who has documented fire-return intervals as often as five years in the northern Sandhills.

Although bison were present throughout the Holocene (Loope 1986), it is unlikely that either fire or bison grazing were significant ecological processes in places or times characterized by active sand dune activity. However, in combination with the on-set of dry, windy conditions, it is possible that fire and bison grazing may have triggered periods of active dune migration. Thus, while fire, in combination with grazing, may be necessary to maintain Sandhills vegetation in its current state, it also may increase the erosion hazard to these rangelands.

\section{Literature Cited}

Anderson, R.C. 1990. The historic role of fire in the North American grasslands. p. 5- 19. In: S.L. Collins and L.L Wallace (eds.), Fire in the North American tallgrassprairie. Univ. Okla. Press, Norman, Okla.

Axelrod, D.I. 1985. Rise of the grassland biome, central North Amer. Bot. Rev. 51:163-202.

Biondini, M.E., A.A. Steuter, and C.E. Grygiel. 1989. Seasonal fire effects on the diversity patterns, spatial distribution and community structure of forbs in the northern mixed prairie, USA. Vegetatio 85:21-31.

Biondini, M.A., and C.E. Grygiel. 1993. Landscape distribution of organisms and the scaling of resources: A hierarchical fractal perspective. Amer. Nat. 141 :(in press).

Bleed, A. and C. Flowerday. 1989. An Atlas of the Sandhills. Conserv. Surv. Div., Int. Agr. Nat. Res., Univ. Nebraska, Lincoln, Nebr.

Bragg, T.B. 1985. A preliminary fire history of the oak/pine forest in northcentral Nebraska. Nebr. Acad. Sci. 95:8.

Bragg, T.B. 1978. Effects of burning, cattle grazing, and topography on vegetation of the choppy sands range site in the Nebraska Sandhills. 1st Internat. Rangeland Congr. Proc. (Denver, Colo.) 1:248-253.

Butler, J.L., and D.D. Briske. 1988. Population structure and tiller demography of the bunchgrass Schizachyrium scoparium to herbivory. Oikos 51:306-312.

Coppock, D.W., and J.K. Detling. 1986. Alteration of bison and blacktailed prairie dog grazing interaction by prescribed burning. J. Wildl. Manage. 50:452-455.

Loope, D.B. 1986. Recognizing and utilizing vertebrate tracks incross section: Cenozoic hoofprints from Nebraska. Palaios 1:141-151.

Mack, R.N., and J.N. Thompson. 1982. Evolution in steppe with few large hooved mammals. Amer. Nat. 119:757-773.

Mullahey, J.J., S.S. Waller, and L.E. Moser. 1990. Defoliation effects on production and morphological development of little bluestem. J. Range Manage. 43:497-500.

Mullahey, J.J., S.S. Waller, and L.E. Moser. 1991. Defoliation effects on yield and bud and tiller numbers of two sandhills grasses. J. Range Manage. 44:241-245.

Plumb, G.E., and J.L. Dodd. 1993. Foraging ecology of bison and cattle on a northern mixed prairie: Implications for natural area management. Ecol. Appl. 4:(in press).

Shaw, J.H., and T.S. Carter. 1990. Bison movements in relation to fire and seasonality. Wildl. Soc. Bull. 18:426-430.

Steuter, A.A., B. Jasch, J. Thnen, and L.L. Tieszen. 1990. Woodland/grassland boundary changes in the middle Niobrara valley of Nebraska identified by $d^{13} \mathrm{C}$ values of soil organic matter. Amer. Midl. Nat. 124:301-308.

Steuter, A.A., E.M. Steinauer, G.L. Hill, P.A. Bowers, and L.L. Tieszen. 1994. Functional spatial scales for bison and pocket gophers in a sandhills prairie landscape. Landscape Ecol. 8:(in press).

Vinton, M.A., D.C. Hartnett, E.J. Finck, and J.M. Briggs. 1993. Interactive effects of fire, bison (Bison bison) grazing and plant community composition in tallgrass prairie. Amer. Midl. Nat. 129:10-18.

Wright, H.A. 1971. Why squirreltail is more tolerant to burning than needleand-thread. J. Range Manage. 24:277-284. 